\title{
Változó biológiai-fizikai sajátosságok és egészségnevelés. A gyermekek növekedési és érési sajátosságai
}

\section{Vitályos Gábor Áron}

Eötvös Loránd Tudományegyetem, Tanító- és Óvóképző Kar, Természettudományi Tanszék

\begin{abstract}
Az emberi szervezet, a felnőttkori testméretek kialakulásáig, nagyon sok változáson megy keresztül. Már az intrauterin élet alatt sok tényező hat a fejlődő embrióra, majd a magzatra, viszont születés után még több hatás fogja érni a szervezetet, befolyásolva a növekedés és fejlődés irányát. Ahhoz, hogy megértsük ezen tényezők hatásmechanizmusát, meg kell ismerkednünk a fejlődés és az érés életkori és nemi sajátosságaival, a testösszetétellel, a testalkattal. A legfontosabb, növekedést és fejlódést befolyásoló tényezők: a táplálkozás, a fizikai aktivitás, a klimatikus viszonyok, a tengerszint feletti magasság, az évszakok váltakozása, a hömérséklet, a szocio-ökonómiai helyzet, a betegségek, és végül, de nem utolsósorban a szülöi szeretet. Fontos, hogy a jövő pedagógusai megismerjék ezeket a tényezőket, a fejlődő gyermeki szervezetre gyakorolt pozitív vagy akár negatív hatásukat. Oktatói munkájuk mellett odafigyelve a gyermekek fejlödésére és növekedésére, kezükben van társadalmunk egészségi állapotának a megörzése.
\end{abstract}

Kulcsszavak: fejlödés, érés, testösszetétel, testalkat, a növekedést és fejlödést befolyásoló tényezők, egészségnevelés

Az emberi szervezet, mint egységes egész, a fogantatás pillanatától a halál pillanatáig folyamatos változásokon megy keresztül. Hol a növekedés és a felépítő folyamatok kerülnek előtérbe, hol a lebontó folyamatok lesznek az uralkodóak az adott életszakasznak és hormonális aktivitásnak megfelelően, de ezt az aktuális állapotot nagymértékben befolyásolhatják a külső környezeti tényezők is.

Fejlődés, érés alatt olyan minőségi változások sorozatát értjük, melyek hatására kevésbé differenciált sajátságú rendszerekből, bonyolultabb, differenciáltabb sajátságú rendszerek keletkeznek. Növekedés alatt viszont méretnagyobbodást okozó változások sorozatát értjük. Ez utóbbi, mennyiségi változást eredményez (Bodzsár, 2003; Farkas, 2008).

Az emberi életút szakaszait, biológiai szempontok alapján, a következőképpen csoportosíthatjuk (Bodzsár, 2003):

- a prenatális lét

- újszülöttkor (1-10. nap),

- csecsemőkor (10. nap-1. év),

- korai gyermekkor (1-3. év),

- első gyermekkor (4-7. év),

- második gyermekkor (lányoknál: 8-11. év, fiúknál: 8-12. év),

- serdülőkor (lányoknál: 12-15. év, fiúknál: 13-16. év),

- ifjúkor (lányoknál: 16-20. év, fiúknál: 17-21. év),

- az érettkor első szakasza (nőknél: 21-35. év, férfiaknál: 22-35. év),

- az érettkor második szakasza (nőknél: 36-55. év, férfiaknál: 36-60. év),

- időskor (nőknél: 56-74. év, férfiaknál: 61-74. év),

- aggkor (75-90. év) és

- hosszú életkor (a 90. évtől).

A prenatális létben, vagyis a méhen belüli életben a fejlődés, míg a születés után, tehát a méhen kívüli életben a növekedés mint életfolyamat kerül túlsúlyba. 
Az érettkor második szakaszáig úgynevezett progresszív életszakaszról beszélhetünk, ugyanis erre az életszakaszra, a rendkívül gyors és erőteljes növekedés és fejlődés a jellemző. Egyszer a testtömeg, máskor a testmagasság növekedése lesz intenzívebb. Mivel a növekedést és fejlődést nagyon sok külső és belső tényező határozza meg, már születéskor sem azonos minden újszülött lehetősége a növekedéshez, a fejlődéshez, és az elérhető maximális életkor eléréséhez (Farkas, 2008). Viszont a növekedésvizsgálatok azt igazolták, hogy minden normális, egészséges, jól gondozott gyermek - nemtől és genetikai eredettől függetlenül - ugyanazt a növekedési mintát követi a születéstöl a szexuális érés befejezéséig (Bodzsár, 2003).

Ugyancsak a növekedésvizsgálatok alapján ismert, hogy a növekedés az újszülött-, csecsemő- és korai gyermekkorban a legintenzívebb. A második gyermekkorban és a serdülőkorban a növekedés intenzitásában már nemi dimorfizmus is kimutatható.

A testmagasság növekedési mértékében figyelemreméltó az ún. serdülökori növekedési lökés. Ekkor, először a lányok, majd a fiúk tömeg, illetve testmagasságának gyarapodásában következik be intenzívebb növekedés, ezért ebben az időszakban a lányok magasabbak és súlyosabbak, mint azonos korú fiú kortársaik (Farkas, 2008) (1. ábra). Egyes szervek, növekedés tekintetében, hasonlatosak a testmagasság növekedéséhez, de mások eltérnek ettől. A pubertás kor másik velejárója a szaporító szervrendszer gyors növekedése, ami a hormonrendszerben történő változásokkal együtt a másodlagos ivari jellegek kialakulását eredményezi, még jobban elkülönítve egymástól a két nemet (2. ábra).
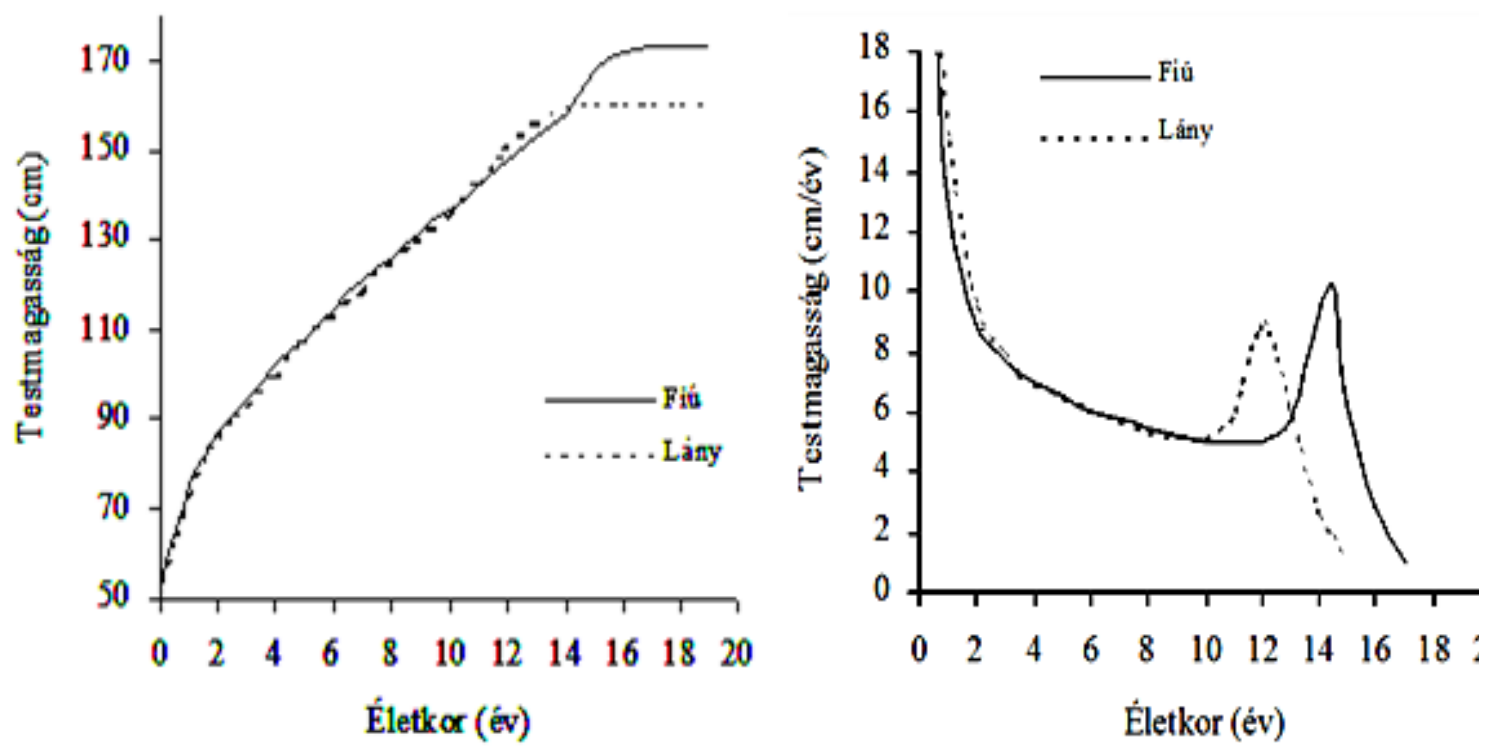

1. ábra: Az átlagos testmagasság életkori változása, valamint növekedési tempója

(Bodzsár, 2003) 


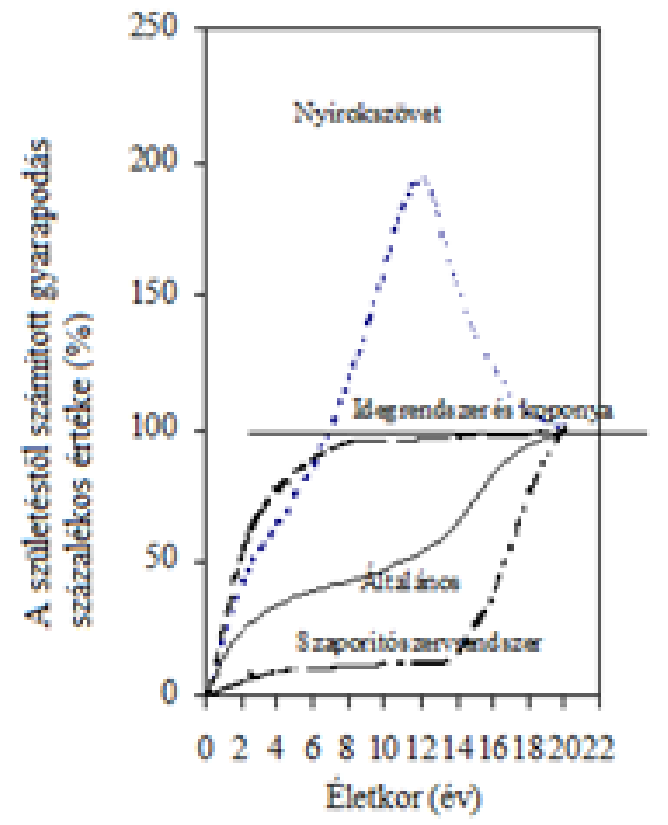

2. ábra: A különböző szövetek növekedési görbéi

(Scammon, 1930)

Ezek a nemi különbségek nemcsak a másodlagos ivari jellegekben nyilvánulnak meg, hanem a testösszetételben is különbségek láthatóak a két nem között (3. ábra).

Testösszetétel alatt, a szervezet, valamint a szervezet szöveteinek felépítésében résztvevő vegyületek (fehérjék, lipidek, ásványi anyagok, víz) mennyiségét és arányát értjük (Bodzsár, 2003; Farkas, 2008). Életünk folyamán a testösszetételünk is változik (1. táblázat).

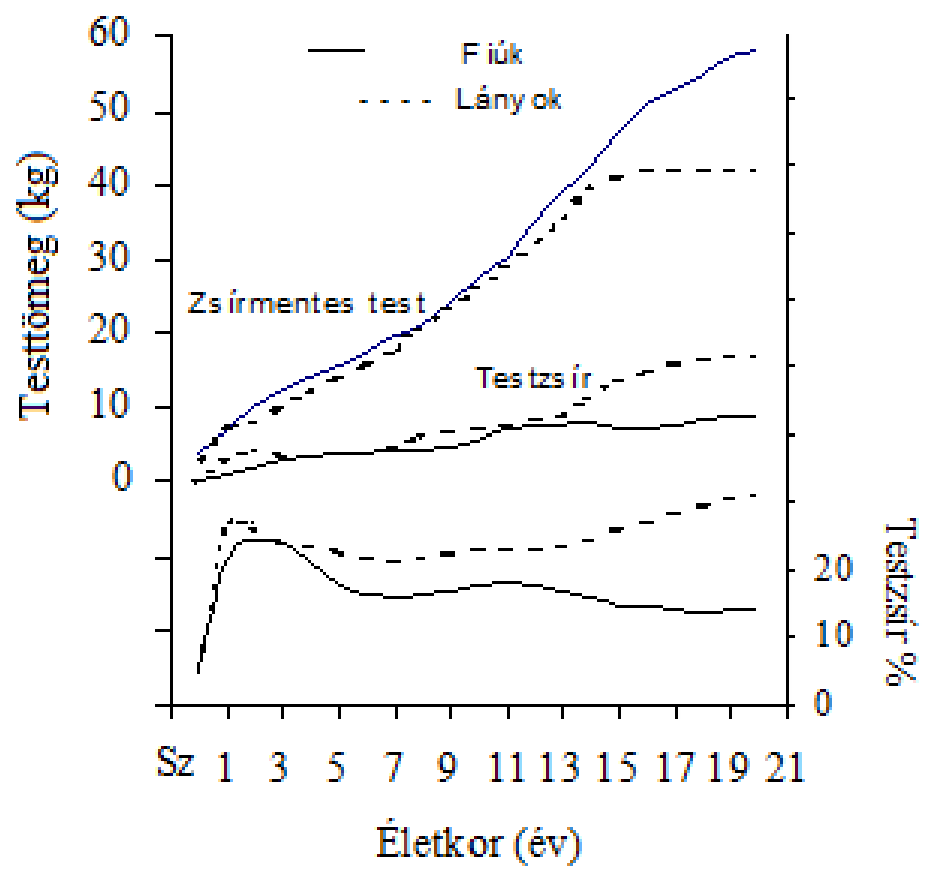

3. ábra: A zsírmentes testtömegnek és a testzsír abszolút és relatív mennyiségének növekedési görbéi (Bodzsár, 2003) 
Változó biológiai-fizikai sajátosságok és egészségnevelés. A gyermekek növekedési és érési sajátosságai

\begin{tabular}{lccccc}
\hline \multicolumn{7}{l}{$\begin{array}{l}\text { Zsírmentes testtömeg } \\
\text { Életkor (év) }\end{array}$} & Víz \% & Protein \% & Ásványi sók \% & $\mathrm{K}+(\mathrm{g} / \mathrm{kg})$ & Sürüség $\left(\mathrm{g} / \mathrm{cm}^{3}\right)$ \\
\hline Férfiak & & & & & \\
Születéskor & 80,6 & 15,0 & 3,7 & 1,92 & 1,063 \\
1 & 79,0 & 16,6 & 3,7 & 2,21 & 1,068 \\
3 & 77,5 & 17,8 & 4,0 & 2,39 & 1,074 \\
5 & 76,6 & 18,5 & 4,3 & 2,49 & 1,078 \\
$7-9$ & 76,8 & 18,1 & 5,1 & 2,40 & 1,081 \\
$9-11$ & 76,2 & 18,4 & 5,4 & 2,45 & 1,084 \\
$11-13$ & 75,4 & 18,9 & 5,7 & 2,52 & 1,087 \\
$13-15$ & 74,7 & 19,1 & 6,2 & 2,56 & 1,094 \\
$15-17$ & 74,2 & 19,3 & 6,5 & 2,61 & 1,096 \\
$17-20$ & 74,0 & 19,4 & 6,6 & 2,63 & 1,099 \\
\hline Nök & & & & & \\
Születéskor & 80,6 & 15,0 & 3,7 & 1,92 & 1,064 \\
1 & 78,8 & 16,9 & 3,7 & 2,24 & 1,069 \\
3 & 77,9 & 17,7 & 3,7 & 2,38 & 1,071 \\
5 & 77,6 & 18,0 & 3,7 & 2,42 & 1,073 \\
$7-9$ & 77,6 & 17,5 & 4,9 & 2,32 & 1,079 \\
$9-11$ & 77,0 & 17,8 & 5,2 & 2,34 & 1,082 \\
$11-13$ & 76,6 & 17,9 & 5,5 & 2,36 & 1,086 \\
$13-15$ & 75,5 & 18,6 & 5,9 & 2,38 & 1,092 \\
$15-17$ & 75,0 & 18,9 & 6,1 & 2,40 & 1,094 \\
$17-20$ & 74,8 & 19,2 & 6,0 & 2,41 & 1,094 \\
\hline
\end{tabular}

1. táblázat. A zsírmentes testtömeg változása a növekedési szakaszban (Bodzsár, 2003)

A testösszetételt vagy közvetlen kémiai vizsgálatokkal határozzák meg, melyek a szervek, szervrendszerek szöveteit alkotó sejtek kémiai összetételét, számát, méretét becslik, vagy elméleti modell alapján különítik el a testösszetevő komponenseket, elsősorban a testünkben lévő zsír mennyiségét vagy arányát a testtömegben (Bodzsár, 2003; Bodzsár és Zsákai, 2004). A 2. táblázat a legismertebb testösszetétel-becslö módszereket foglalja össze.

A leggyakrabban kétkomponenses modelleket használnak: az emberi testet zsírtartalomra és zsírmentes részre bontják, de ismertek három vagy több komponenst elkülönítő modellek is.

Az emberi test teljes zsírmennyisége elhelyezkedése és funkciója szerint, a bör alatt és a zsigerek körül elhelyezkedő, ún. tartalékzsírra (ez adja a zsírtömeg nagyobbik hányadát és mennyisége a környezeti feltételektöl jelentösen függ), valamint a sejtplazma és a sejtközötti állomány zsírjára, az ún. esszenciális zsírra osztható, amelynek mennyisége relatíve állandó (Bodzsár, 2003). 


\begin{tabular}{ll}
\hline Módszer & Becsült változó \\
\hline Víz alatti, gázkiszorításos testsúlymérés & Testsürüség \\
A test 40K tartalmának meghatározása & Víztér és zsírtömeg \\
Izotóp-hígításos eljárás & Víztér és zsírtömeg \\
Neutron-aktiváció (N és Ca izotópokkal) & Sovány testtömeg és ásványi anyag \\
Izotóp-aktivitás mérése & Zsír, izom- és csonttömeg \\
Bioelektromos impedancia analízis & Víztartalom, zsírmentes testtömeg és zsírtömeg \\
Zsíroldékony gázok elnyelődése & Zsírtömeg \\
Vizelet-kreatinin meghatározás & Izomtömeg \\
Fotonabszorpciós eljárás & Csontok ásványi anyag tartalma \\
Mágnesen atommag rezonancia (NMR) & Zsír-, izom- és csonttömeg \\
Komputer-tomográfia & Csont-, izom- és zsírtömeg \\
Ultrahang-vizsgálat & Zsír-, izom- és csonttömeg \\
Antropometria & Zsírmentes és zsírtömeg \\
\hline
\end{tabular}

2. táblázat. A testösszetételt in vivo becslő módszerek összefoglalása (Bodzsár, 2003)

Annak ellenére, hogy mindannyian a Homo sapiens fajba tartozunk, testösszetevő komponenseink nem egyforma mértéküek és eloszlásúak, a különböző mérhető tulajdonságaink is eltérőek lehetnek. Erre már az emberiség nagyon korán felfigyelt, így, a testalkat szerinti különbözőségek vagy éppen hasonlóságok alapján, alkattípusok kezdtek körvonalazódni.

De mi is az a testalkat? Farkas (2008) a következők szerint definiálja: „testalkaton az ember bizonyos morfológiai-fiziológiai jellegegyüttesét értjük, amelyet a genetikai faktorok, valamint a méhen belüli (intrauterin) és születés utáni (extrauterin seupostnatalis) élet hatásai határoznak meg".

Hippokratész (i.e. 460-377) -az ember egészségének titkát testnedvei egyensúlyában vélte megtalálni, ezért a vérmérséklet szerint elkülönített szangvinikus (vérmes), kolerikus (epés), flegmatikus, melankolikus természetet. Szerinte, ha a testnedvek közötti egyensúly felborul, az betegségek kialakulásához vezet. Két alkattípust is elkülönített: az alacsony, telt típust, valamint a magas, szikár típust (Bodzsár, 2003; Farkas, 2008).

Csak a XVIII. század végén és a XIX. század elején született meg az első, olyan típustan, amely elsődlegesen szomatikus jellegek-az emésztőszervek (has), az izomzat és az agy fejlettsége - alapján kategorizált. Így például az ún. francia alkati iskola, a testalkat négy típusát különítette el: a muszkuláris, a respiratorikus, adigesztívés a cerebrális típust (4. ábra) (Bodzsár, 2003; Farkas, 2008).

A XX. század elején, Kretschmer, pszichiátriai betegeket vizsgálva, a különböző betegségeket a testalkattal hozta összefüggésbe. Ezek alapján, négy alkattípust különített el: atletikus, piknikus (tömör), leptoszóm (erötlen, fejletlen) és diszpláziás (félrefejlett) alkatot (5. ábra). Ez utóbbi egy átmeneti alkattípus (Kretschmer, 1921). 
cerebrális típus

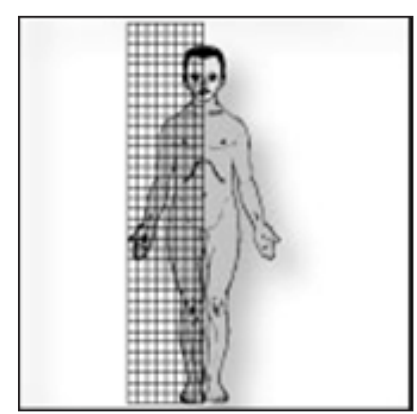

digesztív típus

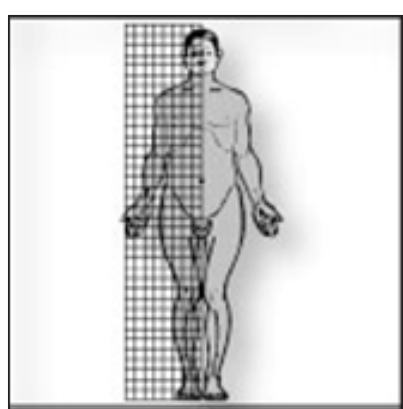

respiratorikus típus

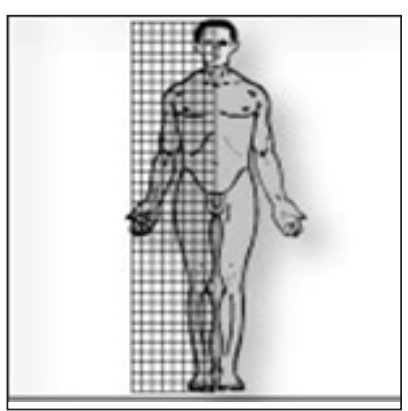

muszkuláris típus

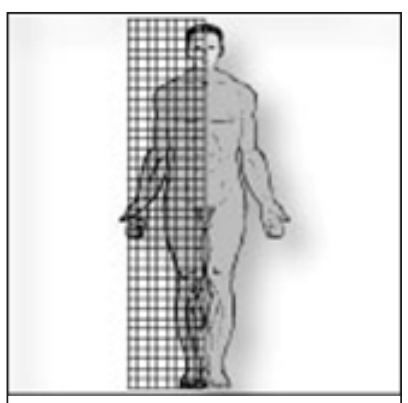

4. ábra: A francia alkattani iskola testalkat típusai

(http://www.bioterapi.ro/aprofundat/index_aprofundat_omul_ particularitati_aspectul_fizic_morfotipuri_generale.html, 2014.10.28.szerint)

piknikus alkat

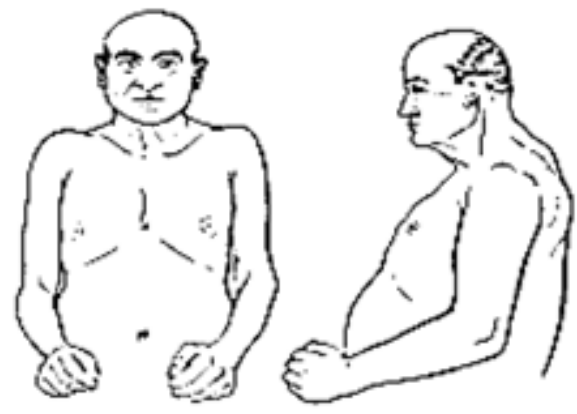

atletikus alkat
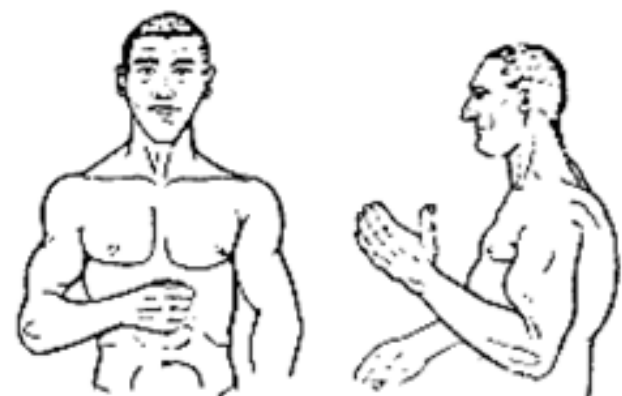

leptoszóm alkat
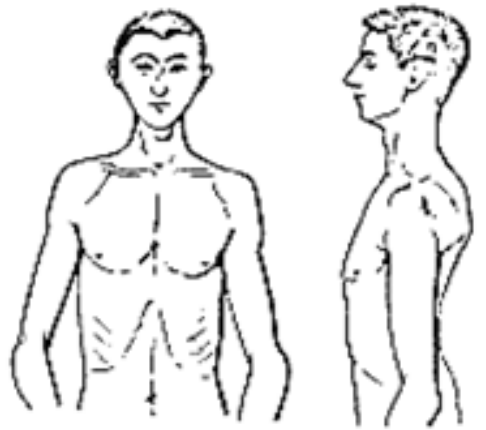

5. ábra: A Kretschmer-féle alkattípusok (Farkas, 2008)

1940-ben, Sheldon egy új fogalmat vezetett be, a szomatotípust: a testalkatot a három csíralemezből kialakult szervek, illetve szervrendszerek egymáshoz viszonyított fejlettségi szintje határozza meg. Testalkat-tipizáló módszerét arra az elvre építette, 
hogy a nagyon változékony egyéni testalkatot három fő komponens különböző kombinációjú együttese határozza meg.

Így a testalkati eltérések attól függenek, milyen mértékben járultak hozzá e szervek, illetve szövetek a külső forma kialakításához.

$\mathrm{E}$ három komponenst (Kretschmerre emlékezve) eredetileg piknoszómiának, szomatoszómiának és leptoszómiának, majd később endomorfiának, mezomorfiának és ektomorfiának nevezte el (6. ábra).

Módszerét szomatoszkópiás szomatotipizálás néven szokták említeni, és eredetileg csak a felnőtt test formájának leírására szolgált (Bodzsár, 2003; Farkas, 2008).

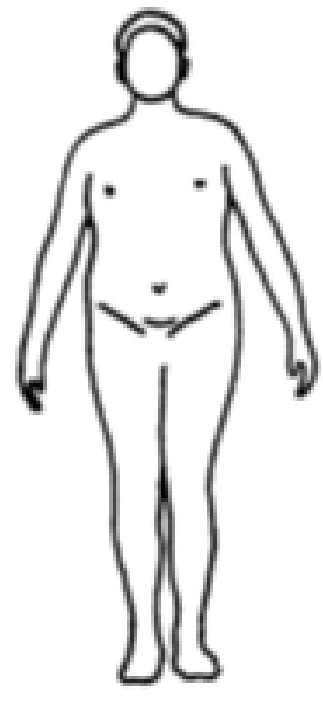

$\underline{\text { Endomorf }}$

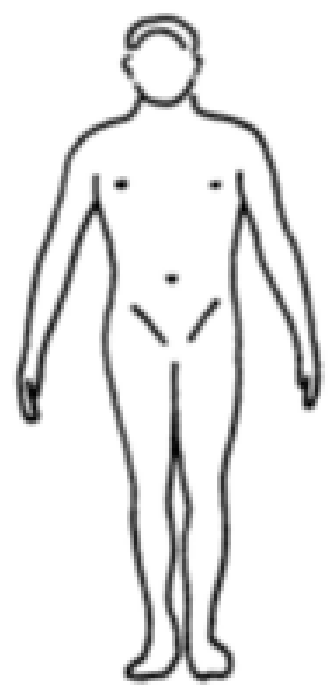

$\underline{\text { Mezomorf }}$

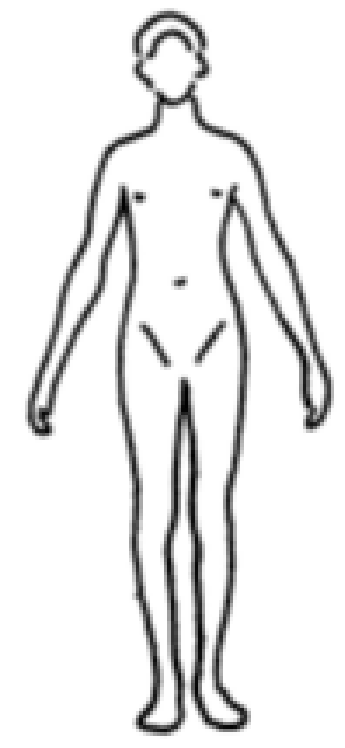

Ektomorf

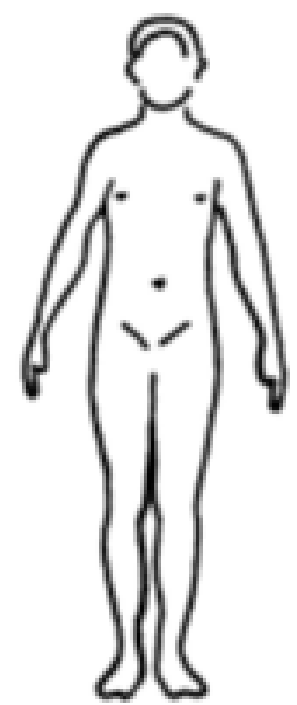

Centrális (átlag-típus)

6. ábra: A Sheldon-féle szomatotípusok (Farkas, 2008)

1971-ben Heath és Carter, továbbfejlesztve a sheldoni osztályozási módszert, egy olyan testalkat tipizáló módszert hoztak létre, mely érzékeny a testalkat életkori változásaira is, így mindkét nemnél és bármely életkorban használható. Ez a ma leginkább elterjedt testalkatbecslő módszer.

Ök is megtartották a három alkatösszetevőt, melyeket továbbra is egységben, kombinációként kell felfogni:

- az I. komponens, vagy endomorfia, melyben a test relatív zsírtartalma nyer kifejezést;

- a II. komponens, vagy mezomorfia, ez a muszkulo-szkeletális robuszticitás kifejeződése; és

- a III. komponens, vagy ektomorfia, melyben a test tömegének a magasság menti eloszlása rejlik, vagyis a relatív linearitás.

Az egyes komponensek mértékének megállapításához különböző testméretek adatainak a felvétele szükséges, majd egy skálán jellemzik azokat (Bodzsár, 2003; Farkas, 2008).

Az egyedi szomatotípusok, a komponensek egymáshoz viszonyított értékei közötti azonosságok, illetve különbözőségek alapján, 13 kategóriába sorolhatók (7. ábra). 


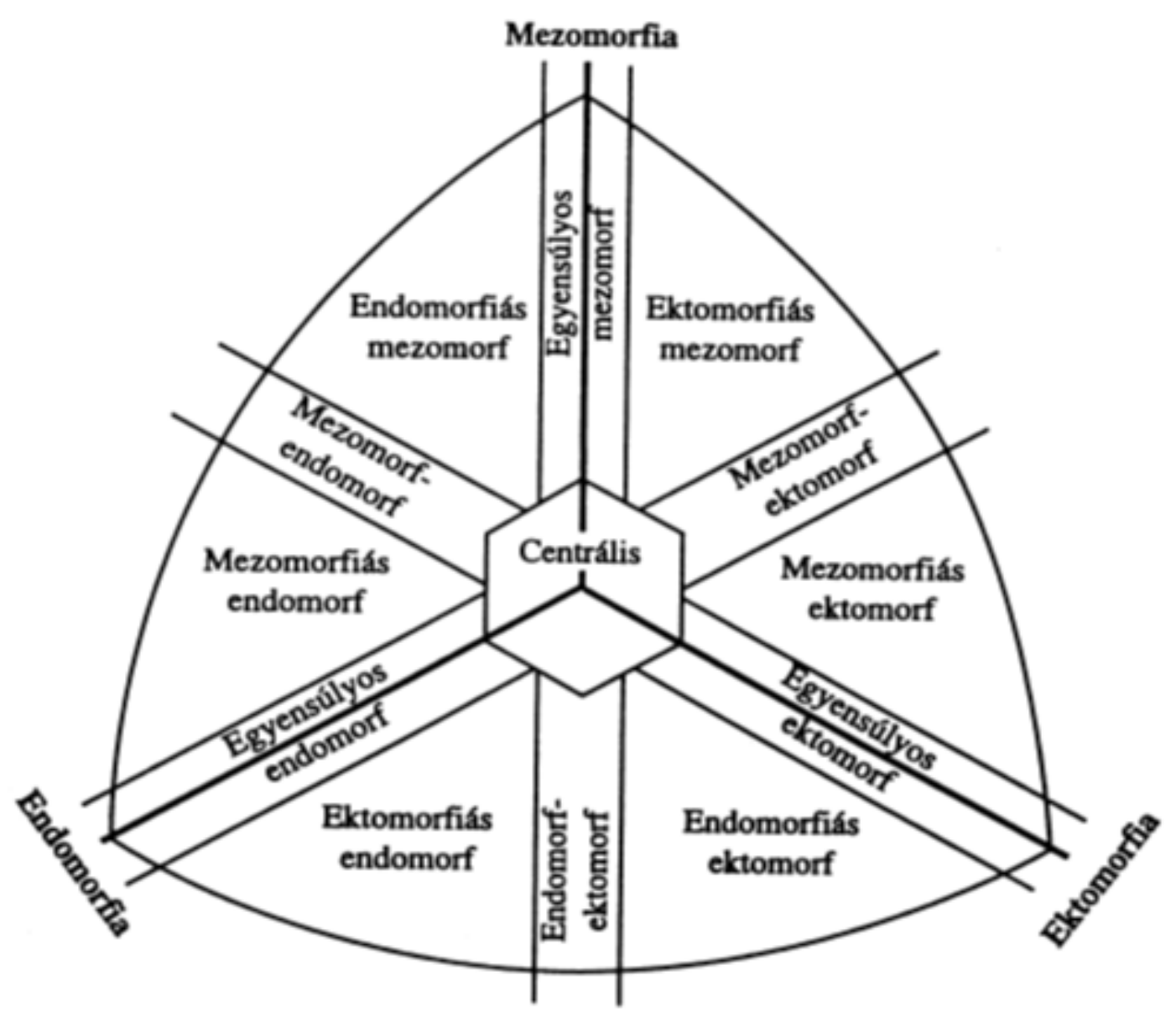

7. ábra: A szomatotípus kategóriák elhelyezkedése az alkathálón (Bodzsár, 2003).

A szomatotípus komponensek életkori változásainak vizsgálatakor megfigyelhető, hogy a prepubertás korú, de különböző nemű gyermekek szomatotípusának változásában lényeges különbséget nem találunk, mindkét nem egyaránt a túlnyomó részt mezomorfiás régióban helyezkedik el. A pubertáskori változások idején, a fiúknál a csontozat-izomzat robuszticitásának, a leányoknál pedig az endomorfiának a fokozódása figyelhető meg. 18 éves korra manifesztálódnak a nemre jellemző szomatotípus jellemzők: fiúk esetén a mezomorfiás ektomorf, a leányoknál pedig az ektomorfiás endomorf típus (Vitályos és mtsai, 2012) (8. ábra).

Fiúk

uroevora

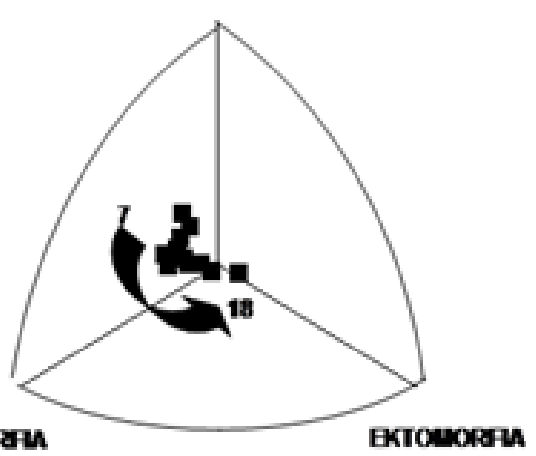

Lányok

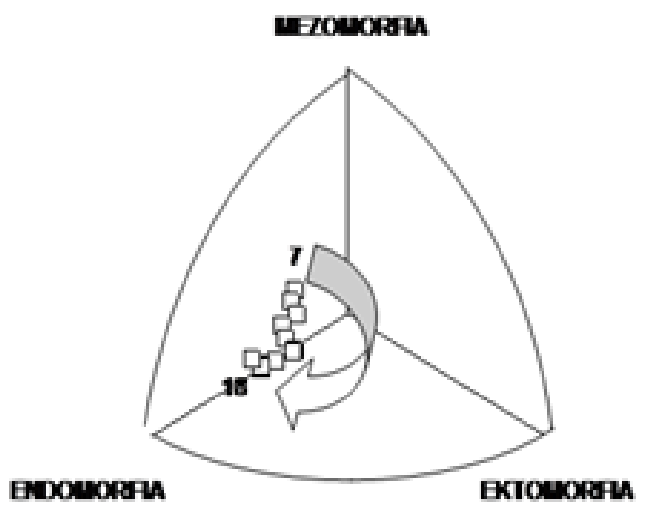


A növekedés, érés, mint láthattuk, nemcsak genetikailag vannak meghatározva, hanem nagymértékben a környezeti tényezőktől is függnek. A továbbiakban tekintsük át az utóbbiakat.

Táplálkozással az ember, szövetei, sejtjei számára szükséges tápanyagok felvételét biztosítja, mely anyagok nemcsak a struktúrát, hanem a müködést is biztosítják, nemcsak az érintett sejtek, hanem az egész szervezet számára.

Esszenciális minden olyan tápanyag, amelynek hiányában az egyébként kiegyensúlyozott étrend sem biztosítja a fejlődő szervezet normális növekedését, érését, illetve a szervezet fennmaradását, müködését (Bodzsár, 2003). Az ember esszenciális tápanyagait a 3. táblázat foglalja össze.

\begin{tabular}{lll}
\hline Szénhidrátok & Ásványi anyagok & Vitaminok \\
glükóz & kalcium & Zsírban oldódók \\
Lipidek & noszfor & $\mathrm{A}$ (retinol) \\
linolénsav & kálium & $\mathrm{D}$ \\
& kén & $\mathrm{E}$ (tokoferol) \\
Fehériék & klór & $\mathrm{K}$ \\
Aminosavak & magnézium & Vízben oldódók \\
leucin & vas & B1 (tiamin) \\
izoleucin & szelén & B2 (riboflavin) \\
\hline lizin & cink & niacin (PP-faktor) \\
metionin & mangán & biotin \\
fenilalanin & réz & folsav \\
treonin & kobalt & $\mathrm{B}_{6}$ (piridoxin) \\
triptofán & molibdén & $\mathrm{B}_{12}$ (cianokobalamin) \\
valin & jód & pantoténsav \\
hisztidin & króm & $\mathrm{C}$ (aszkorbinsav) \\
& fluor & \\
& vanádium & Víz \\
& ón & \\
& nikkel & \\
& szilícium & \\
\hline
\end{tabular}

3. táblázat. Az ember esszenciális tápanyagai (Bodzsár, 2003)

$A z$ ember nem tápanyagokat, hanem ételeket fogyaszt. Az ételkészítés során felhasznált nyersanyagok összetétele és élettani hasznosithatósága is jelentősen változhat a hely és idő függvényében. Ha nagyobb az energiabevitel, mint a felhasználás, akkor egyre növekvő testzsírfelhalmozást figyelhetünk meg, ami előbb-utóbb túlsúlyossághoz vagy obezitáshoz (kövérséghez) vezet. Viszont, ha az egyensúly a másik irányba tolódik el, és az energiafelhasználás fog a bevitel fölé magasodni, a szervezetet másfajta kóros állapotok fogják jellemezni, melyeket a tápanyag- és/vagy energiahiány okoz. Ezeket együttesen malnutríciónak nevezzük. A túltápláltság vagy a krónikus fehérje- (kwashiorkor) vagy/és energiahiányos (marasmus) étrend növekedési zavarokat okoz. A súlyos protein- és energiahiányos táplálkozási rendellenességekben szenvedő gyermekek rehabilitálhatók, de a regenerációs idő függ a táplálkozási rendellenesség időtartamától (Bodzsár, 2003). 
Gyermekkorban az elégtelen táplálkozás a növekedés lelassulását okozza és késlelteti az érést. Ha az éhezés még a pubertáskorban is tart, a végleges felnőttkori testméretek is kisebbek lesznek.

Súlyos növekedési és fejlődésbeli elmaradottságot okoz a talaj és a növények jód-, cink- és magnéziumhiánya (Bodzsár, 2003).

A szervezet energiaszükséglete függ az alapanyagcserétől, melyet több tényező is befolyásol: életkor, nem, testmagasság, testtömeg (ahol nagyon fontos az izomtömegnek, illetve a zsírtömegnek az aránya), táplálkozás, a környezet hőmérséklete.

Hogy megőrizhessük egészségünket, helyesen kell táplálkoznunk, vagy legalábbis meg kell tanulnunk helyesen táplálkozni.

A helyes táplálkozás alapszabályai:

- fedezi a szükségletet energiából és minden esszenciális tápanyagból,

- nem jelent túlzott bevitelt egyetlen anyagból sem,

- nem tartalmaz toxikus, illetve egészségkárosító vegyi komponenst az egészségre veszélyes mennyiségben,

- megfelelö mennyiségben tartalmaz élelmi rostot,

- mikrobiológiai szempontból biztonságos,

- jó érzékszervi tulajdonságokkal rendelkezik (íz, szín, szag).

Ezek mellett az ún. táplálékpiramisokat kell szem előtt tartanunk (9. ábra), valamint megfontolandó a Magyar Tudományos Akadémia Élelmiszertudományi Komplex Bizottsága, az Országos Élelmezés- és Táplálkozástudományi Intézet és a Magyar Táplálkozástudományi Társaság együttesen elfogadott álláspontja a helyes táplálkozásról „A helyes táplálkozás 12 mérföldköve” címmel:

1. minél változatosabb, minél többféle élelmiszer elfogyasztása

2. zsír: kevés

3. só: kevés

4. édességek: hetenként legfeljebb egyszer, kétszer

5. tej vagy tejtermék: fél liter/nap

6. nyers gyümölcs, zöldségféle: rendszeresen, naponta többször

7. kenyér: barna, köret: inkább a burgonya és párolt zöldségfélék, mint a rizs, tészta

8. étkezési gyakoriság: napi 4-5, lehetőleg azonos időpontban

9. ital: ivóvíz

10. nincsenek tiltott táplálékok, csak kerülendő mennyiségek:

- bőséges fogyasztásra javasolt: gyümölcsök, zöldség- és főzelékfélék, hal, továbbá barna kenyér, burgonya.

- Mérsékelt fogyasztásra javasolt: nem zsíros húsok és húskészítmények, zsírszegény tej és tejtermékek, zsiradékok (célszerü a zsír helyett olaj, a vaj helyett margarin), tojás, tészta, száraz hüvelyesek.

- Kerülni javasolt: édességek, fagylalt, cukrozott készítmények (befőtt, lekvár is), zsíros húsok, zsíros ételek, tejszín, cukor, cukros üdítők, só, tömény italok, sör, bor.

11. fontos: dohányzás teljes mellőzése, rendszeres testmozgás

12. testtömeg mérése. 


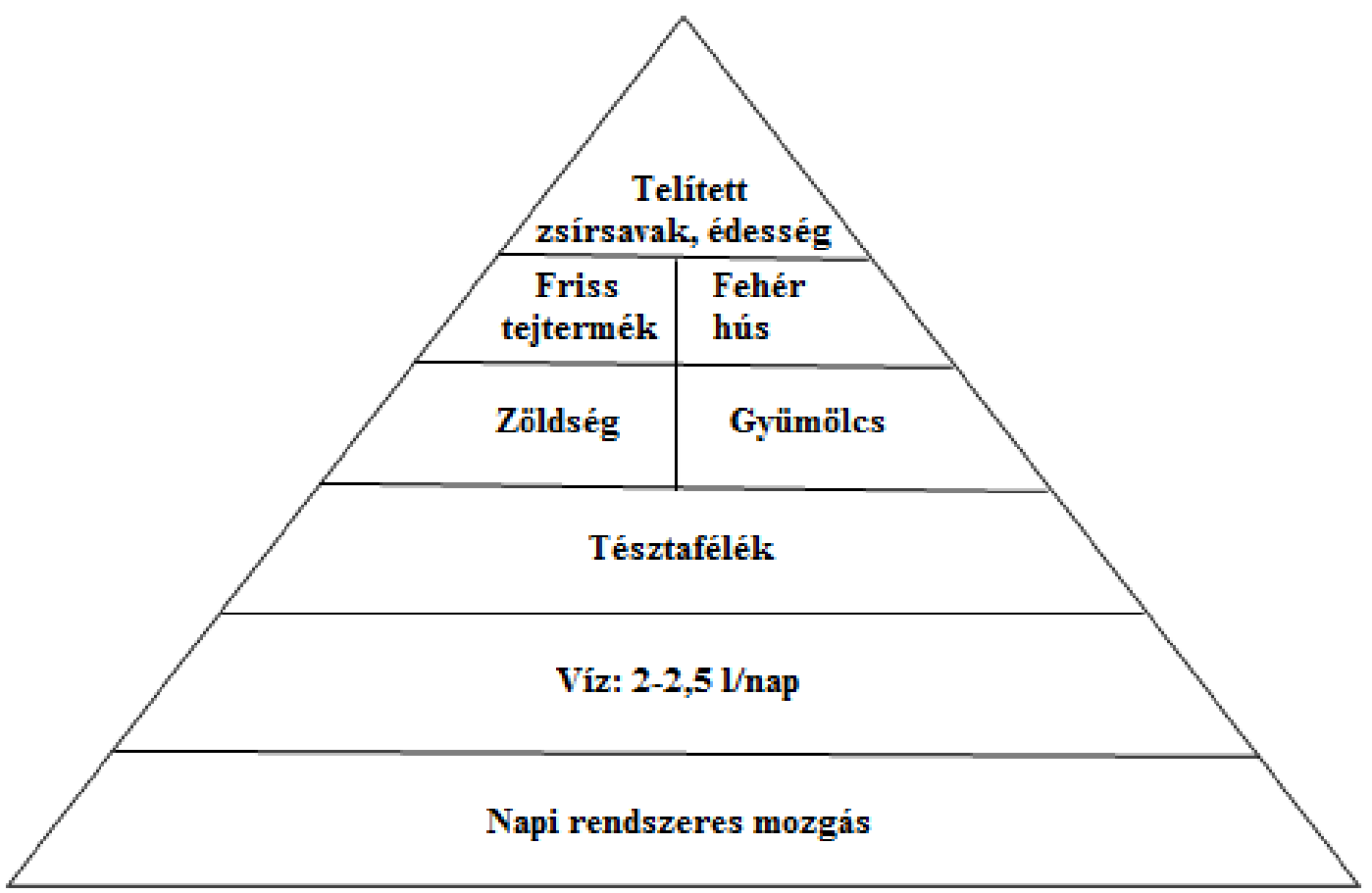

9. ábra: Táplálékpiramis

Az elhízás nemcsak a felnőtt lakosság körében tapasztalható egyre nagyobb prevalenciájú egészségügyi probléma, hanem már az egyedfejlődés korábbi stádiumaiban - gyermek-, serdülö- és ifjúkorban - is megfigyelhető (Lobstein és mtsai, 2004). Hazánkban is egyre növekszik nemcsak a kövér felnőttek, hanem a kövér gyermekek száma is (Dóber, 1995, 1996/97; Erhardt, 2007).

Az elhízás számos súlyos egészségügyi szövődményt vonhat maga után, mint:

- szív- és érrendszeri megbetegedések,

- támasztó- és mozgatórendszeri megbetegedések,

- a vérszérum koleszterinszintjénk megemelkedése,

- onkológiai és nőgyógyászati kórképek kialakulása,

- cukorbetegség, valamint egyéb metabolikus elváltozások kialakulása (Siervogel és mtsai, 1998).

Ha az energiabevitel és -felhasználás közti egyensúly az energiabevitel javára billen el, a szervezet ezt az energiatöbbletet zsírként (trigliceridek) raktározza el, vagy bőr alatti zsír formájában, vagy a belső szervek köré rakódva. Ennek értelmében az elhízásnak két típusát különíthetjük el: az alma, illetve a körte típusút. A körte típusú elhízás esetén az újonnan kialakított zsír föleg az alsó végtag felső régiójára lokalizálódik, míg az alma típusú elhízás nemcsak a hasi régió bőr alját érinti, hanem a belső szerveket is, ami jelentősen megnöveli a későbbi szív- és érrendszeri betegségek kialakulását (10. ábra). 

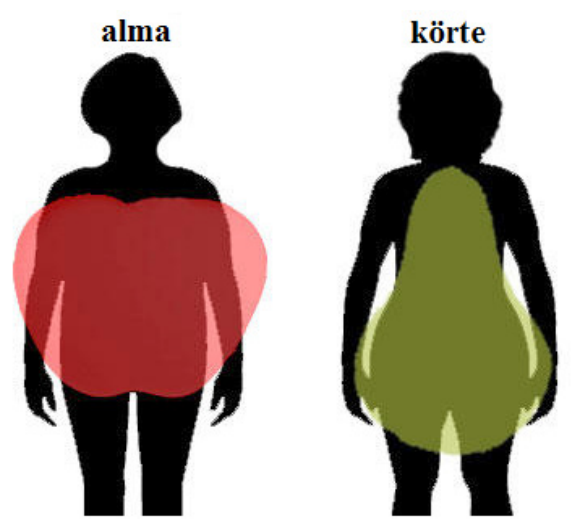

10. ábra: Az alma, illetve a körte típusú elhízás

(http://www.macosz.hu/az-alma-es-korte-tipusu-elhizas.html, 2014.10.28.)

Magyarországon, a 3-18 éves korcsoportban, a fiúk 7-12\%-a, a lányok 13-18\%a kórosan sovány, a fiúk 10-19\%-a, a lányok 5-12\%-a túlsúlyos, a fiúk 3-5\%-a, a leányok 1-3\%-a kövér (Zsákai és mtsai, 2007).

A felnőttkori kövérség kockázata nagyobb a kövér gyermekeknél. Az 1-5 éves korban túlsúlyos gyermekeknek több mint a 1/4-e, a 3-9 éves korúaknak több mint 1/3-a, a 10-13 éves korúaknak pedig több mint 4/5-e felnőttkorban is kövér lesz (Bodzsár, 2003). Ezért nagyon fontos odafigyelni, hogy már gyermekkorban elsajátítódjon az egészséges táplálkozás és a helyes életvitel.

A táplálkozás mellett nagyon fontos, hogy odafigyeljünk a mindennapi fizikai aktivitásra, ami nem a versenysportot jelenti, hanem a mindennapi aktív tevékenységet.

A 11. ábrán látható az iskolai testnevelési órákon kívül végzett fizikai tevékenység gyakorisága, 7-18 éves magyar gyermekek esetében, ami a következőképpen alakul: mindkét nemnél jelentősen dominál a heti 2-4 alkalommal végzett testnevelési órán kívüli fizikai tevékenység. A fiúknál gyakoribb, a lányoknál ritkább a napi rendszerességü testmozgás. A fiúknak csak 10 \%-a nem mozog a testnevelési órákon kívül, míg a lányoknál ez az érték eléri a több mint 20 \%-ot! Tehát a fiúk esetében nagyobb az aktív életet folytató gyermekek százaléka, mint a lányoknál. Mindkét nemnél, a kor előrehaladtával, a heti fizikai tevékenységek mennyisége csökkenő tendenciát mutat (Vitályos és mtsai, 2012).

fiúk

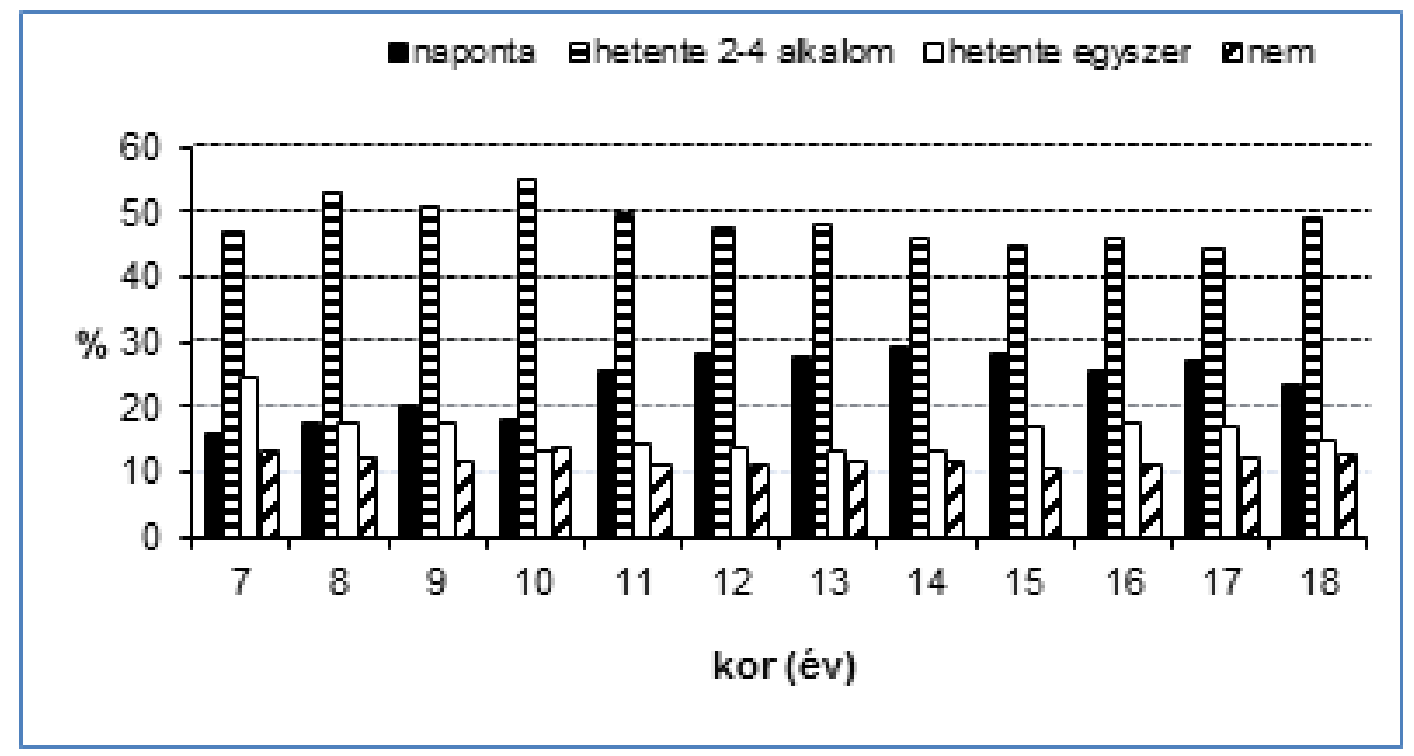


lányok

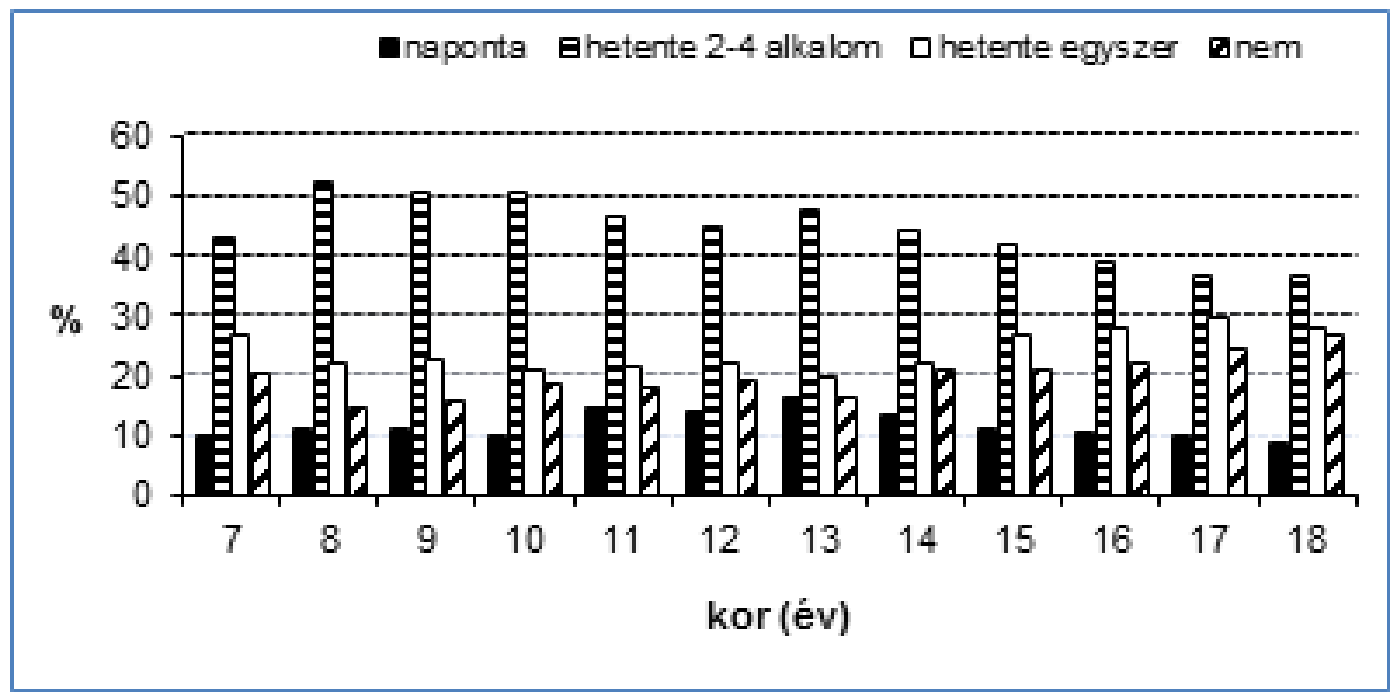

11. ábra: Az iskolai testnevelési órákon kívül végzett fizikai tevékenység gyakorisága (Vitályos és mtsai, 2012)

Sajnálatos módon, a mai gyermekeknél egyre gyakoribb a szabadidő inaktív tevékenységgel való eltöltése. Ilyen tevékenység pl. a televíziózás, számítógépezés. Hasonló tévézési szokások figyelhetők meg mindkét nemnél (12. ábra).

Pubertás korig egyre csökken a nem tévézők száma, míg a posztpubertás éveiben ez a szám újra növekedésnek indul. Ez azzal magyarázható, hogy pubertás korban a gyerekek kezdik magukat egyre jobban kivonni a szülői irányítás alól, míg posztpubertásban az egyre jobban rájuk nehezedő „kényszer” (tanulás, érettségire, felvételire való készülés) miatt mellőzik az ilyenfajta tevékenységet.

Ugyanezt a tendenciát mutatja azok görbéje, akik „csak” napi egy, vagy kevesebb, mint napi egy órát televízióznak a hétköznapokon.

Az úgymond sokat televíziózó gyerekek görbéjénél fordított tendenciát látunk, amit szintén magyaráz az előbbi felvetés. Ezen gyermekek 13-14 éves korban majdnem elérik az igen magas 60 \%-ot (Vitályos és mtsai, 2012).

fiúk

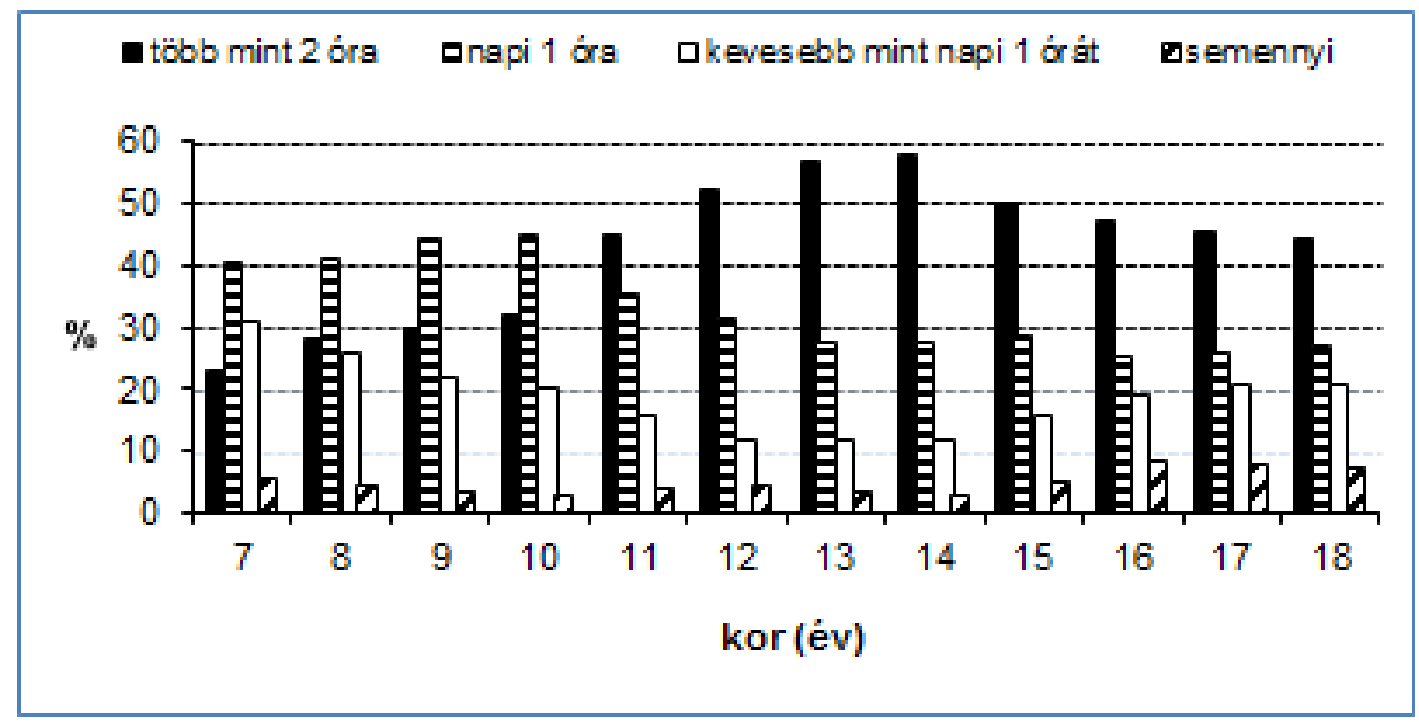


lányok

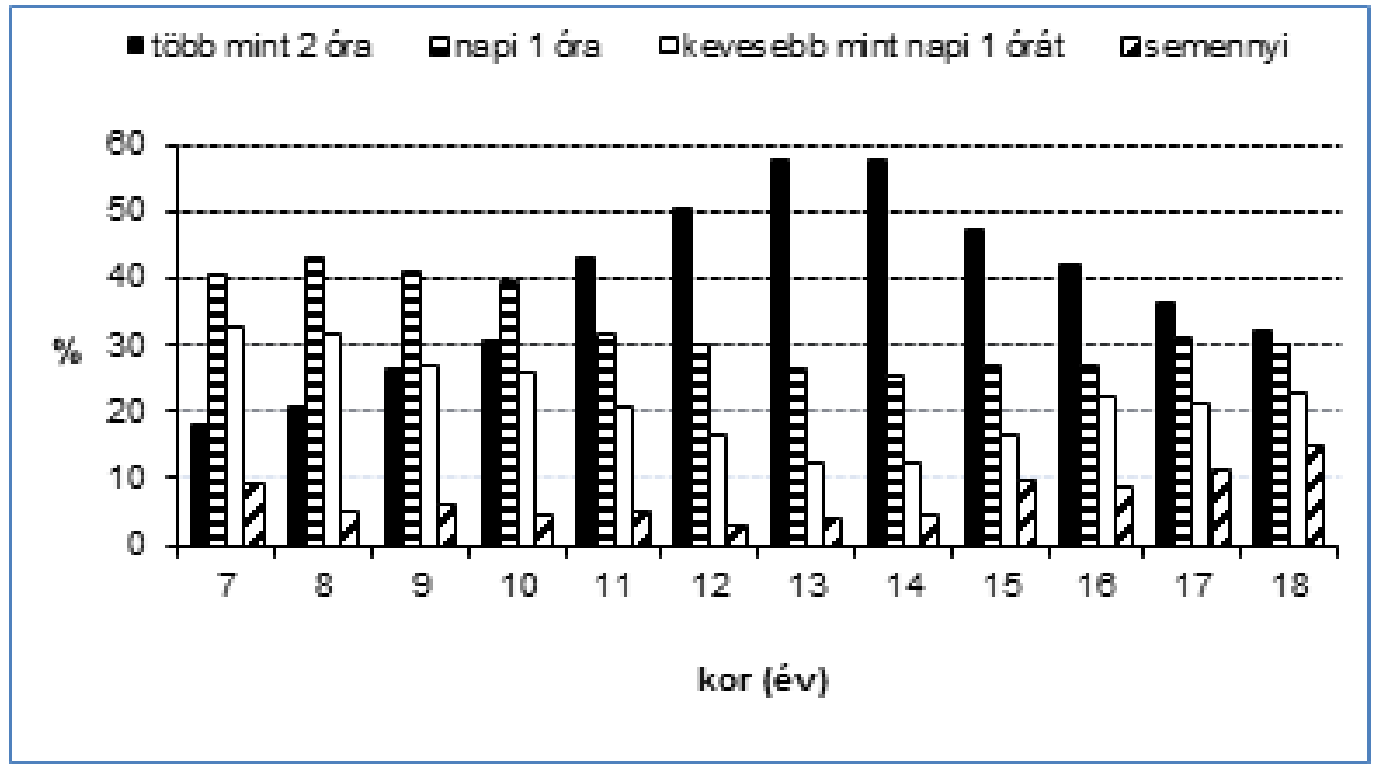

12. ábra: A hétköznapokon, televíziózással eltöltött idő gyakorisága (Vitályos és mtsai, 2012)

A számítógépezés tekintetében kissé változik a helyzet. Érdekes módon, a fiúk sokkal több időt töltenek számítógépezéssel, mint a lányok. Mindkét nemnél szembeötlő, hogy a kor előrehaladtával a gyermekek egyre többet használják a számítógépet (13. ábra).

fiúk

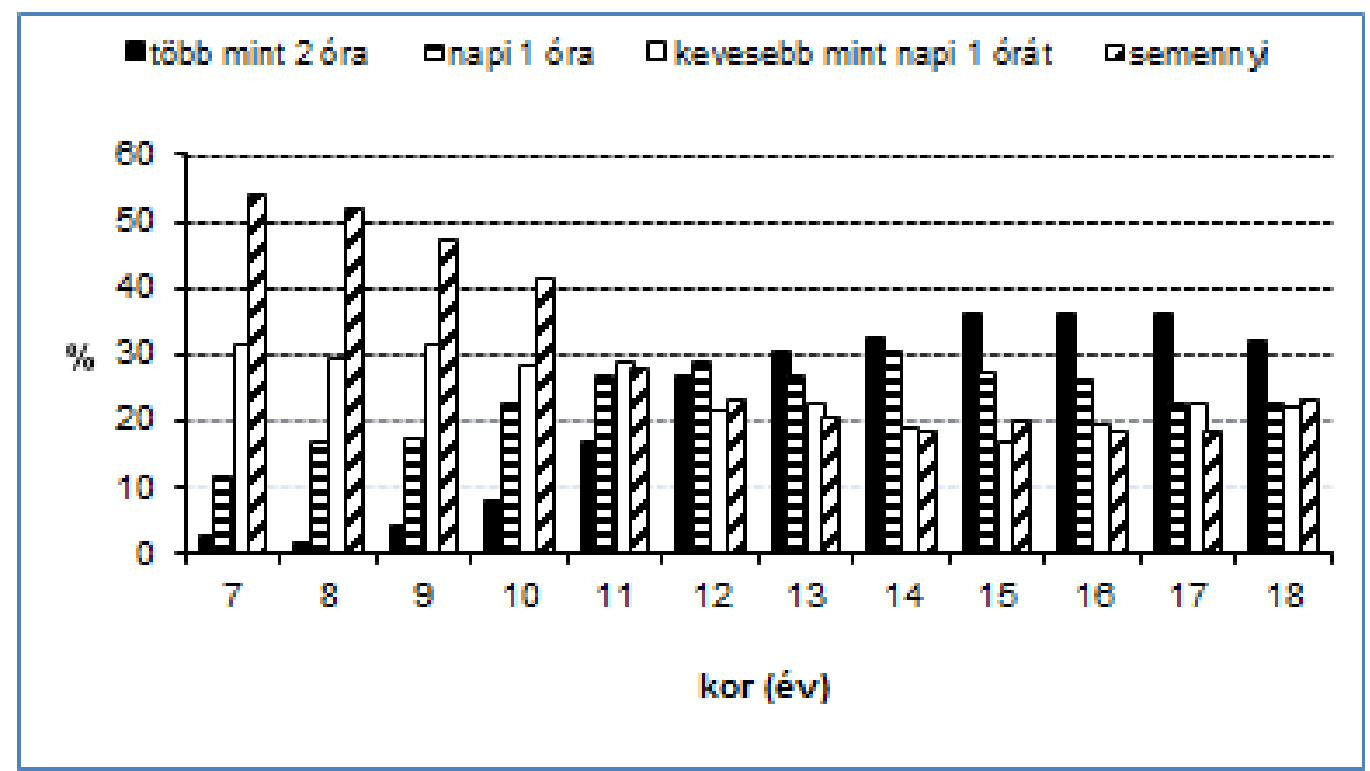


lányok

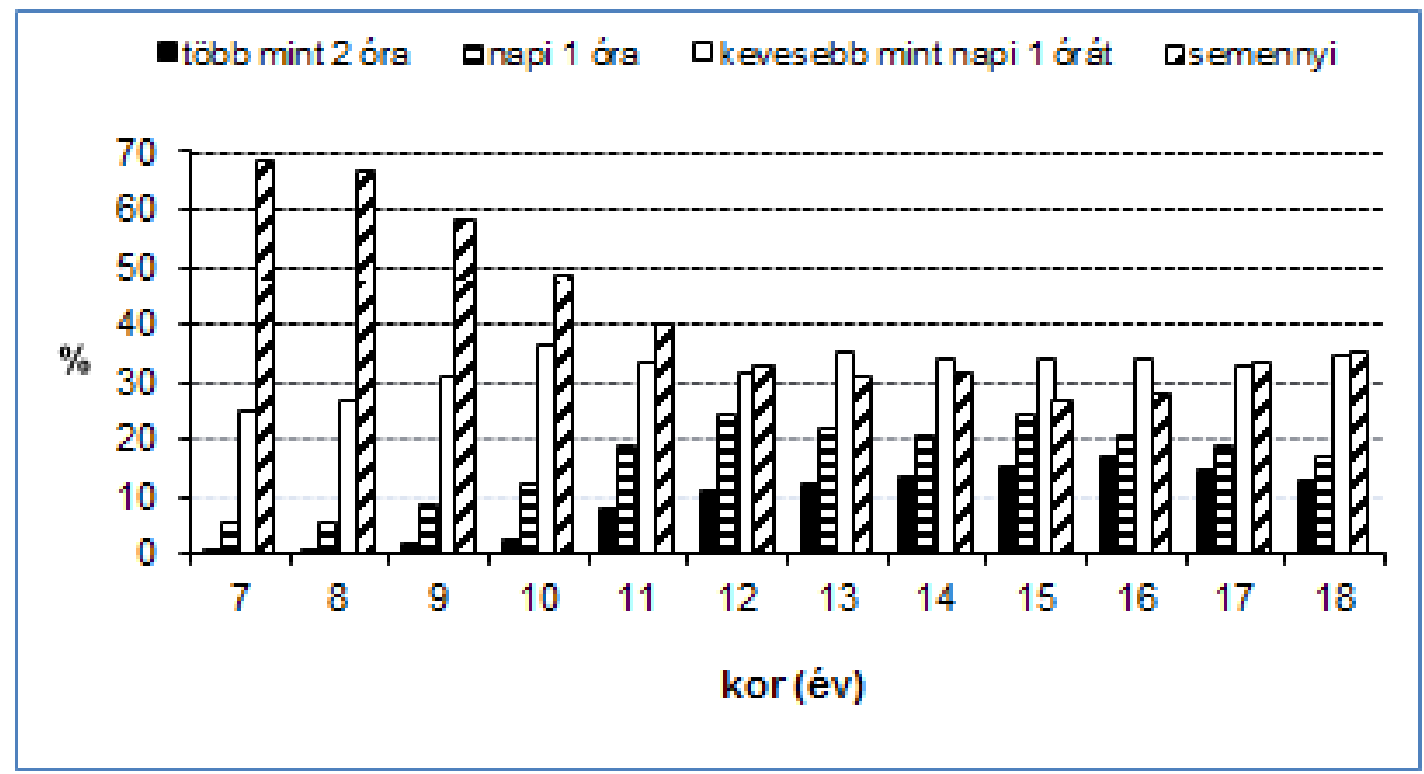

13. ábra: A hétköznapokon, számítógépezéssel eltöltött idő gyakorisága

(Vitályos és mtsai, 2012)

A gyermekek életkor szerinti fizikai aktivitását a 14. ábra mutatja be. Eszerint, a gyermekek egyre kevesebb fizikai aktivitást végeznek pubertás korig, ami után jelentős nemi különbség mutatható ki: a fiúk fizikai aktivitásában egy újabb emelkedés figyelhető meg, míg a lányoknál stagnál a szint.

fiúk

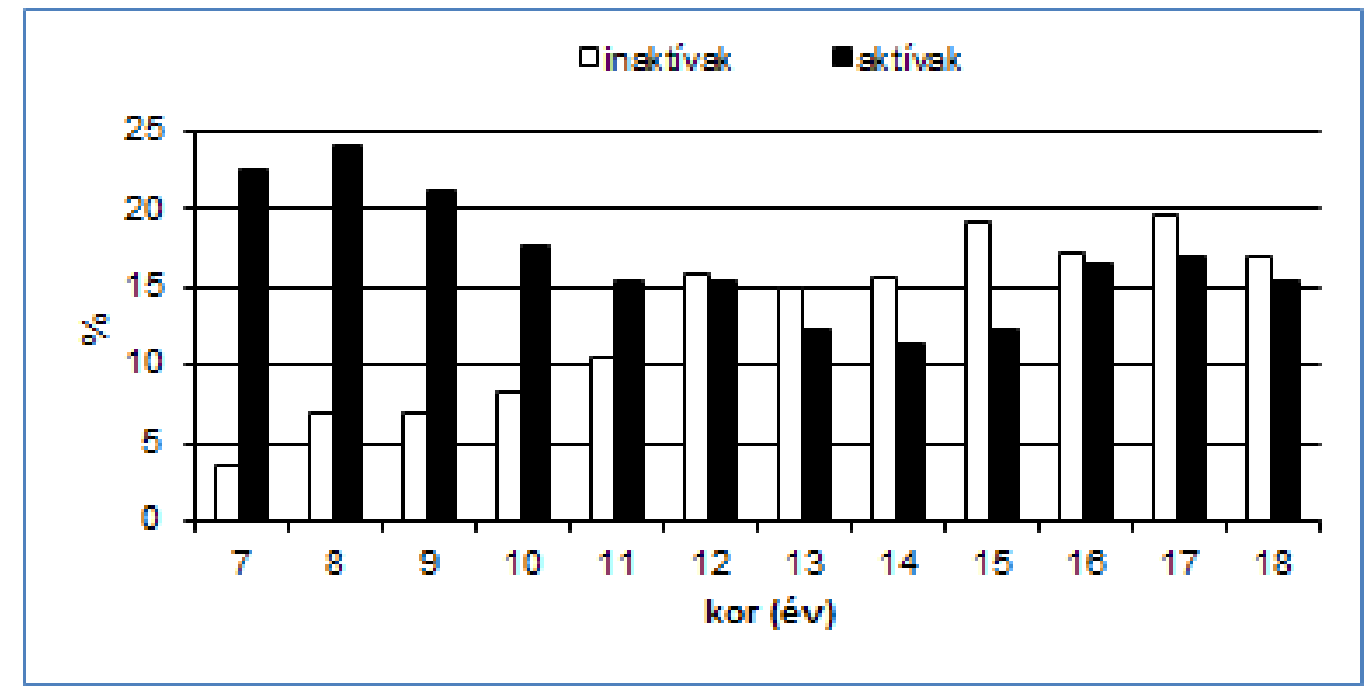


Változó biológiai-fizikai sajátosságok és egészségnevelés. A gyermekek növekedési és érési sajátosságai

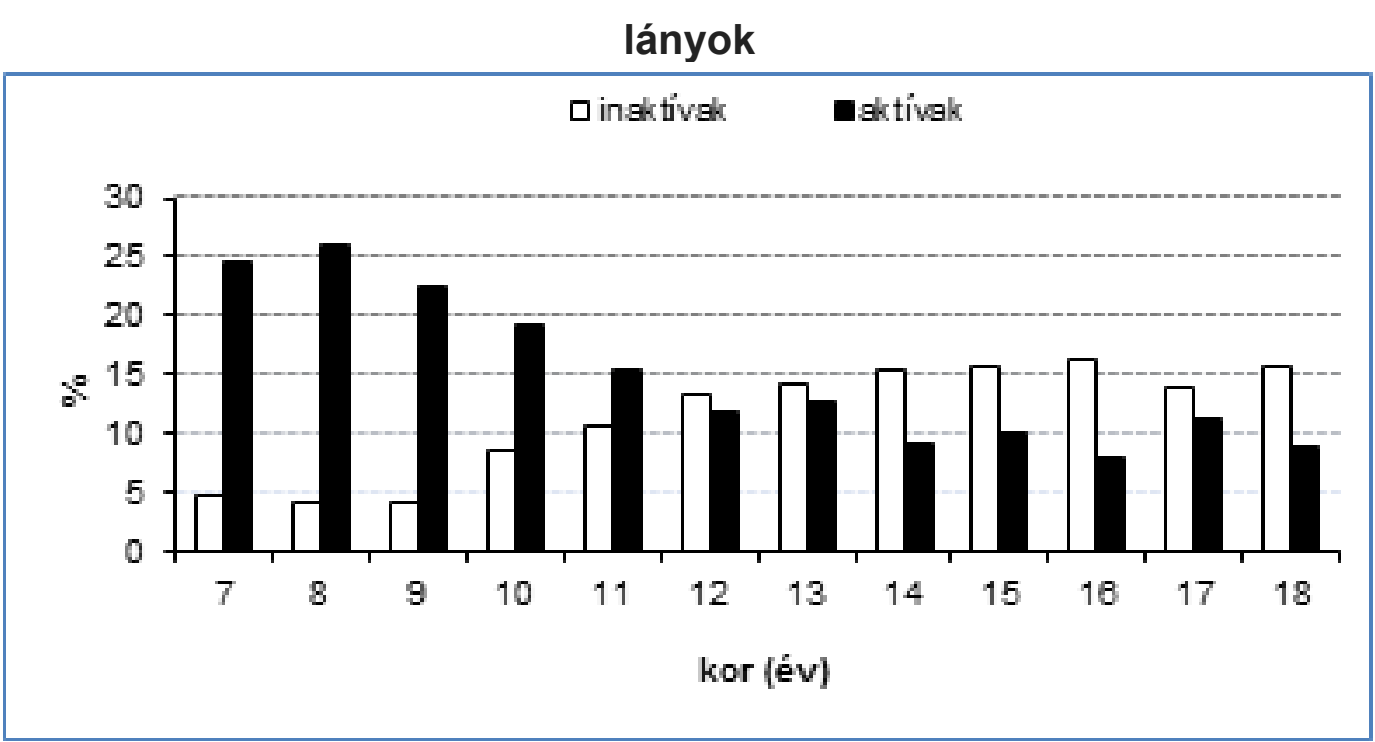

14. ábra: Az aktív és inaktív alcsoportok megoszlása (Vitályos és mtsai, 2012)

Ezzel ellentétes tendenciát mutat az inaktivitás: pubertás korig egyre növekszik a szintje, miután egy közel állandó szintre áll be (Vitályos és mtsai, 2012).

Nem lehet eléggé hangsúlyozni a fizikai aktivitás fontosságát, nemcsak gyermekés ifjúkorban, mikor ezek a tevékenységek hozzájárulnak a növekedés és fejlődés normális ütemének a megtartásához, hanem felnőtt- és időskorban is, hogy a szervezet egészségi állapotát fenntarthassuk.

A környezeti tényezők (természeti és társadalmi) között vannak olyanok, amelyek nem egyszerüen csak a táplálkozási feltételekre hatnak, hanem az emberre mint élö, biológiai szervezetre közvetlen befolyást is gyakorolnak (Bodzsár, 2003).

Az éghajlat, a klimatikus viszonyok és föleg az adott terület átlagos hőmérséklete hatással van az anyagcsere-folyamatok sebességére, ami által befolyásolja a növekedés és érés tempóját.

A klimatikus viszonyokhoz való alkalmazkodás következtében, a tropikus környezetben élő rasszok testalkata általában lineárisabb, testfelületük tömegükhöz képest nagy, alsó végtagjaik relatíve hosszabbak, ezáltal hőleadásuk kedvezőbb. Ezzel szemben, a hideg övben élök rövidebb végtagokkal, de hosszú, megnyúlt törzzsel rendelkeznek, ami a hő megtartásnál kedvezőbb (Bodzsár, 2003; Bogin, 1988).

A tengerszint feletti nagy magasság, ahol alacsonyabb a légköri nyomás, alacsonyabb a levegő lokális oxigénkoncentrációja, magasabb az UV- és a kozmikus sugárzás szintje, alacsonyabb a hőmérséklet, az emberi szervezet számára nagyobb megterhelést jelent az életfolyamatok ellátása. Az ilyen környezetben élök között a születési súly kisebb, az érés késik, sőt a termékenység is alacsonyabb. A nagy magasságban élő emberi populációk vizsgálatakor bebizonyosodott, hogy az itt élő gyermekek alacsonyabbak és könnyebbek, mint alacsonyabb tengerszint felettimagasságban élő társaik (Bodzsár, 2003; Bogin, 1988).

Az évszakok váltakozása is hatással van úgy a hossz-, mint a tömegnövekedésre. Mivel tavasszal a nappalok hosszabbodnak, nagyobb a szervezetet érő fény menynyisége, megjelennek az étrendünkben a friss zöldségek és gyümölcsök. $A$ bennük lévő vitaminok, ásványi anyagok és nyomelemek révén, kedvező hatással vannak a növekedésre, a vitaminokat és más, a szervezet számára fontos anyagokat nélkülöző téli hónapok után. Serken a sejtek osztódási képessége, ami sejtszám-szaporulathoz vezet. Ezt közvetetten a testméretek növekedésében, illetve tömeggyarapodásban láthatjuk (Bodzsár, 2003; Bogin, 1988). 
A különböző szocio-ökonómiai tényezők is hatással vannak a növekedésre és fejlődésre. Már a XIX. század elején megállapították, hogy a nyomor által sújtott osztályokhoz tartozó szülők gyermekei lassabban nőnek, végleges testmagasságuk is alacsonyabb, mint a jobb körülmények között élö társaiké (Bodzsár, 2003).

Napjainkban is, a különböző szociális hátterü gyermekek testméreteikben és érettségi státusukban lényegesen különbözhetnek egymástól. Egy jómódú család gyermeke többnyire magasabb és súlyosabb, és az érés egyes stádiumait is korábban éri el, mint kevésbé jómódú családban született kortársa. A gyermek fejlődésére és érésére hatással van szűk környezete, úgymint a szülök iskolai végzettsége és foglalkozása, a család mérete, az egy före jutó kereset, a lakás komfortjának szintje, ugyanakkor a tág környezet is érzékelteti hatását, mint a lakóhely urbanizáltsági foka és lélekszáma, az egészségügyi ellátottság szintje, etnikum, nemzetiség (Bodzsár, 2003; Bogin, 1988).

A koruknak és magasságuknak megfelelő tápláltsági szintű gyermekeknél a rövid ideig tartó betegségek nem, viszont a hosszan tartó betegségek lassíthatják a növekedést és az érést. A gyógyulást követően a növekedés mértékének gyorsulását tapasztalhatjuk, ami addig tart, míg a gyermek el nem éri azt a méretet, ami rá jellemző lett volna, a betegség méretnövekedést gátló hatása nélkül.

A klímának (hőmérséklet, páratartalom stb.), a személyi és a környezeti higiéniának (pl. az ivóvíz tisztasága, a kézmosás fontossága) jelentős befolyása van a fertőző betegségek előfordulási gyakoriságára (Bodzsár, 2003).

A gyermekeket körülvevő környezet emocionális és pszichikai hatásai is befolyásolják növekedésüket, fejlődésüket (Bodzsár, 2003).

Szülői szeretetet, gondoskodást nélkülöző gyermekeknél érzelmi elhanyagoltság alakul ki, ami gátolja az emésztőenzimek elválasztását és a tápanyagfelvételt. Ennek következtében még akkor is gyengébb tápláltság alakul ki a gyermeknél, ha elegendő ennivaló áll a rendelkezésére (Bodzsár, 2003).

Szekuláris trenden (évszázados irányultság) az antropológiai jellegek kialakulásának az olyan tempóbeli és méretbeli, nem véletlenszerü, egy irányba tartó változásait értjük, amelyek az adott földrajzi régióban élő populáció egymást követő generációiban követhetők nyomon. A legszembetűnőbb, így a legismertebb változás az ember felnöttkori testmagasságában nyilvánult meg. A szexuális érés korábbi életkorra tolódása is ilyen változásnak tekinthető (Bodzsár, 2003).

A megfigyelések többségében a magasabb termet, a nagyobb testtömeg és a korábban jelentkező érés szekuláris folyamatai együttesen jelentkeztek, és a táplálkozás minőségében és mennyiségében, valamint az általános egészségi állapotban mutatkozó javuláshoz társultak. Ezért a pozitív szekuláris változásokat a társadalmi jólét mutatójaként lehet értelmezni.

Manapság a legtöbb gazdaságilag fejlett régióban élő populációban, a felnőttkori testmagasság növekedésének és az érés korábbra tolódásának mértéke lecsökkent. Ez azzal magyarázható, hogy az adott régió környezeti tényezői elérték hatásfokuk maximumát, vagy már nem fejlődnek, alakulnak tovább, vagy az adott populáció genetikai potenciáljának érvényre jutásához szükséges optimális környezeti feltételek már adottak (Bodzsár, 2003).

Mint látjuk, az emberi fejlődést, növekedést mennyi, egymástól független tényező befolyásolja, de melyek között akár bonyolult kapcsolatrendszerek is kialakulhatnak. Ezért nagyon fontos, hogy a jövő pedagógusai megismerjék ezeket, és oktatói munkájuk mellett odafigyeljenek a felnövekvő következő generációk fejlődésére és növekedésére, hogy a későbbiekben, ha nem is javítani, de meg tudjuk őrizni társadalmunk egészségi állapotát. 


\section{Irodalom}

Bodzsár Éva (2003): Humánbiológia. Fejlődés: növekedés és érés. ELTE Eötvös Kiadó, Budapest.

Bodzsár Éva és Zsákai Annamária (2004): Humánbiológia. Gyakorlati kézikönyv. ELTE Eötvös Kiadó. Budapest.

Bogin, B. (1988): Patterns of human growth. Cambridge studies in biological anthropology. Cambridge University Press, Cambridge.

Dóber, I. (1995): Changes of incidence of obesity in children during the last decade (Preliminary study). Anthrop. Közl. 37; 89-91.

Dóber, I. (1996/97): The prevalence of obesity and superobesity among schoolchildren of Pécs in the 1990-s. Anthrop. Közl. 38; 149-155.

Erhardt Éva (2007): Gyermekkori elhízás, okok és következmények, Doktori (PhD) értekezés, Pécs.

Farkas L. Gyula (2008): Fejezetek a biológiai antropológiából. JATEPress, Szeged.

Kretschmer, E. (1921): Körperbau und Charakter, 25. Aufl. Springer, Berlin, Göttingen, Heidelberg.

Lobstein, T.,Baur, L., Uauy, R. (2004): Obesity in children and young people: a crisis in public health. Obesity Review, 5 (Suppl. 1); 4-104.

Scammon, R. E. (1930): The measurement of the body in childhood. In: Harris, J. A., Jackson, C. M., Paterson, D. G. and Scammon, R. E. (Eds): The Measurement of Man. University of Minnesota Press, Minneapolis. 173-215.

Siervogel, R., Wisemandle, W., Guo, S., Chamlea, W., Towne, B., Roche, A. (1998): Adult changes in body composition are associated with changes in cholesterol levels: the Fels longitudinal study. Appl. Radiat. Int. 49; 727.

Vitályos, G. Á., Zsákai, A. Bodzsár, É. (2012): A magyar gyermekek és serdülök testfejlettségi státusza az életmód (a fizikai aktivitás és a táplálkozási szokások) tükrében. In: Darvay Sarolta (szerk.) Tanulmányok a gyermekkori egészségfejlesztés témakörben. Eötvös Loránd Tudományegyetem, Budapest. 145-196.

Zsákai, A., Jakab, K., Karkus, Zs., Tóth, K., Kern, B., Vitályos, Á.G., Lichthammer, A., Balázsi, Sz. és Gábor, Zs. (2007): New Hungarian national cut-off points of BMI for screening childhood underweight, overweight and obesity. Anthrop. Közl. 48; 21-30. 